\title{
A COMPARISON BETWEEN CONICrAIY BOND COAT AND ZIRCONIA PLASMA SPRAYED COATINGS ON CREEP TESTS
}

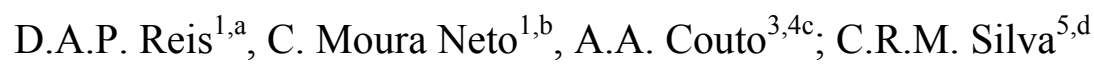 \\ F. Piorino Neto ${ }^{7, e}$, M.J.R. Barboza ${ }^{8, f}$
}

${ }^{1}$ Instituto Tecnológico de Aeronáutica, ITA, São José dos Campos, 12228-904, Brazil.

${ }^{3}$ Instituto de Pesquisas Energéticas e Nucleares, IPEN, São Paulo, Brazil.

${ }^{4}$ Universidade Presbiteriana Mackenzie, UPM, São Paulo, Brazil.

${ }^{2}$ Universidade de Brasília,DEM, UNB, Brasília, 70910-900, Brazil.

${ }^{2}$ Comando-Geral de Tecnologia Aeroespacial, IAE, São José dos Campos, 12228-904, Brazil.

${ }^{3}$ Escola de Engenharia de Lorena, EEL, USP, Lorena, 12600-000, Brazil.

adanielireis@hotmail.com, ${ }^{b}$ mneto@ita.br, ${ }^{c}$ acouto@ipen.br, ${ }^{d}$ cosmeroberto@gmail.com, effiorino@iae.cta.br, ${ }^{\mathrm{f}}$ mibarboza@uol.com.br

Thermomechanical and electrical properties of zirconia-based ceramics have led to a wide range of advanced and engineering ceramic applications like solid electrolyte in oxygen sensors, fuel cells and furnace elements and its low thermal conductivity has allowed its use for thermal barrier coatings for aerospace engine components. A comparison between CoNiCrAlY bond coat and zirconia plasma sprayed coatings on creep tests of the Ti-6Al-4V alloy was studied. The material used was commercial Ti-6Al-4V alloy. Yttria (8 wt.\%) stabilized zirconia (YSZ) with a CoNiCrAlY bond coat was atmospherically plasma sprayed on Ti-6Al-4V substrates by Sulzer Metco Type $9 \mathrm{MB}$. Constant load creep tests were conducted on a standard creep machine in air on coated samples, at stress levels of $520 \mathrm{MPa}$ at $500^{\circ} \mathrm{C}$ to evaluate the oxidation protection on creep of the Ti-6Al-4V alloy. Results indicate that the creep resistance of the ceramic coating was greater than metallic coating.

Keywords: plasma-sprayed coatings, Ti-6Al-4V, creep.

\section{Introduction}

The affinity of titanium for oxygen is one of the main factors that limit the application of titanium alloys as structural materials at high temperatures. Oxidation results in the loss of material by oxide scale growth and embrittlement of the alloy by dissolved oxygen $[1,2]$. The high solid solubility of oxygen in titanium results in material loss and in the formation of hard and brittle layer during elevated temperature air exposure [3]. Advances have been observed in the development of titanium alloys with the objective of improving the creep properties, although the surface oxidation limits the use of these alloys in temperatures up to $600^{\circ} \mathrm{C}$. The development of titanium alloys with the objective of improving the creep properties have been observed, although the surface oxidation limits the use of these alloys in temperatures up to $600^{\circ} \mathrm{C}$ [4].

A substantial part of the creep research has been devoted to Ti-6Al-4V due to its industrial and technological importance. Its creep properties in air have been well documented. However, its creep behavior in nitrogen atmosphere and plasma-sprayed coatings for oxidation protection has only rarely been investigated. 
Improvements in aero gas turbine performance in terms of power, efficiency and weight have necessitated the use of high specific-strength low-density materials. Titanium alloys, in general, readily absorb oxygen leading to oxidation and alpha case formation when exposed to high temperatures $\left(>500^{\circ} \mathrm{C}\right)$, in air. This is known to severely limit the high temperature capability of alloys in terms of their mechanical properties. In order for titanium alloys to be utilized more effectively at higher temperatures, the ingress of oxygen must be reduced, if not prevented completely [5].

Plasma spraying is an established technique for the deposition of coatings. Applications include ceramic thermal barrier coatings for gas turbine engine components and the reclamation of worn parts. Plasma spray processing also lends itself nicely to the fabrication of ceramic matrix composites. It is applicable to wide range of materials. The only requirement is that the material to be sprayed does not decompose, sublime, or otherwise react in the plasma flame [6].

Thermal barrier coatings (TBCs) have been widely studied over the past 20 years because they increase the durability and efficiency of gas turbine engines by allowing an increase in turbine inlet temperature and by reducing the amount of cooling air required by the hot-section components. It has been reported that applications of such coatings throughout the combustion chamber and early stages of the turbine would save an operator around $1-2 \%$ of fuel cost, translating into savings of over $\$ 10$ million per annum for some companies [7]. Thermal barrier coating (TBC) systems, consisting of yttria partially stabilized zirconia (YSZ), thermally grown oxide (TGO) and a metallic bond coat, are finding applications for thermal protection of hot-section parts in gas turbine engines. The insulating characteristic of the YSZ ceramic coatings and the oxidation / corrosion resistance of the metallic bond coats provide improvement in performance and efficiency for these engines [8].

Plasma sprayed yttria stabilized zirconia (YSZ) coatings are used as isolative and corrosion resistant layers in high temperature applications such as gas turbine and diesel engines to enable higher working temperatures. Plasma sprayed YSZ coatings, often referred to as thermal barrier coatings (TBCs), with their porous microstructure and ceramic nature provide good heat insulation to the main metal component. A NiCrAlY bond coat layer is applied to enhance adhesion strength between the metal component and YSZ coating. In addition, this NiCrAlY bond coat provides oxidation resistance to the main metal component at high temperatures [9].

The aim of the present paper was estimate the influence of the plasma-sprayed coatings for oxidation protection on creep of the Ti-6Al-4V alloy, focusing on the comparison between CoNiCrAlY bond coat and zirconia plasma sprayed coatings on creep tests.

\section{Experimental procedure}

The material chosen for the present study was hot-forged $12.7 \mathrm{~mm}$ diameter rod of commercial Ti-6Al-4V alloy with the same specifications as published by ASTM [10]. The microstructure consists of equiaxed $\alpha$ grains with average size about $10 \mu \mathrm{m}$. The $\beta$ phase is present in the $\alpha$ grain boundaries. Tensile testing was performed at 600 in air according to ASTM standard E 21 specification [11]. The tensile properties are summarized in Table 1 namely, $0.2 \%$ yield stress (YS), ultimate tensile stress (UTS), elongation (EL) and reduction of area (RA).

Yttria (8 wt.\%) stabilized zirconia (YSZ) (Metco 204B-NS) with a CoNiCrAlY bond coat (AMDRY 995C) was atmospherically plasma sprayed on Ti-6Al-4V substrates by Sulzer Metco Type 9 MB. The initial creep stress levels were determined from the elevated temperature tensile properties given in Table 1. Constant load creep tests were conducted on a standard creep machine in air at stress level of $520 \mathrm{MPa}$ at $500^{\circ} \mathrm{C}$. Samples with a gage length of $18.5 \mathrm{~mm}$ and a diameter of $3.0 \mathrm{~mm}$ were used for all tests. The creep tests were performed according to ASTM E139 standard [12]. 
Table 1 - Tensile properties of Ti-6Al-4V alloy.

\begin{tabular}{ccccc}
\hline $\mathrm{T}\left({ }^{\circ} \mathrm{C}\right)$ & YS (MPa) & UTS (MPa) & EL (\%) & RA (\%) \\
\hline 500 & 521 & 638 & 30 & 73.6 \\
\hline
\end{tabular}

\section{Results and discussion}

Representative creep curves of Ti-6Al-4V are displayed in Figure 1 in air and nitrogen atmospheres in coated and uncoated samples at $520 \mathrm{MPa}$. Ti-6Al-4V alloy exhibits a normal creep curve consisting well-defined primary, secondary and tertiary stages. There is a relatively short initial period of decreasing primary creep rate that is associated with hardening due to the accumulation of dislocations. However, most of the creep life is dominated by a constant creep rate that is thought to be associated with a stable dislocation configuration due to recovery and hardening process $[13,14]$.

Results from the creep tests at $500^{\circ} \mathrm{C}$ are summarized in Table 2, which show the values of primary creep time $\left(t_{p}\right)$ defined as time to the onset of secondary creep, secondary creep rate (\& \&), strain at fracture $\left(\varepsilon_{\mathrm{f}}\right)$, time to rupture $\left(\mathrm{t}_{\mathrm{f}}\right)$ and reduction of area $(\mathrm{RA})$.

Table 2 - Creep data at $500^{\circ} \mathrm{C}$.

\begin{tabular}{|c|c|c|c|c|c|c|}
\hline Coating & $\sigma(\mathbf{M P a})$ & $\mathbf{t}_{\mathbf{p}}(\mathbf{h})$ & $\underset{s}{\mathbf{( 1 / h}} \mathbf{h}$ & $\mathbf{t}_{\mathbf{f}}(\mathbf{h})$ & $\boldsymbol{\varepsilon}_{\mathbf{f}}$ & $\mathbf{R A}(\mathbf{m})$ \\
\hline Ceramic & 520 & 0.24 & $3.4 \times 10^{-2}$ & 2.24 & 0.1056 & 45.73 \\
\hline Metallic & 520 & 0.0667 & $4.4 \times 10^{-2}$ & 1,7167 & 0.1318 & 57.32 \\
\hline
\end{tabular}

The highest values of $t_{p}$ and the reduction of the steady-state creep rate demonstrate that the higher creep resistance of Ti-6Al-4V is observed in ceramic samples. This fact is related to the oxidation protection on creep that the ceramic plasma-sprayed coatings offer to the Ti-6Al-4V alloy.

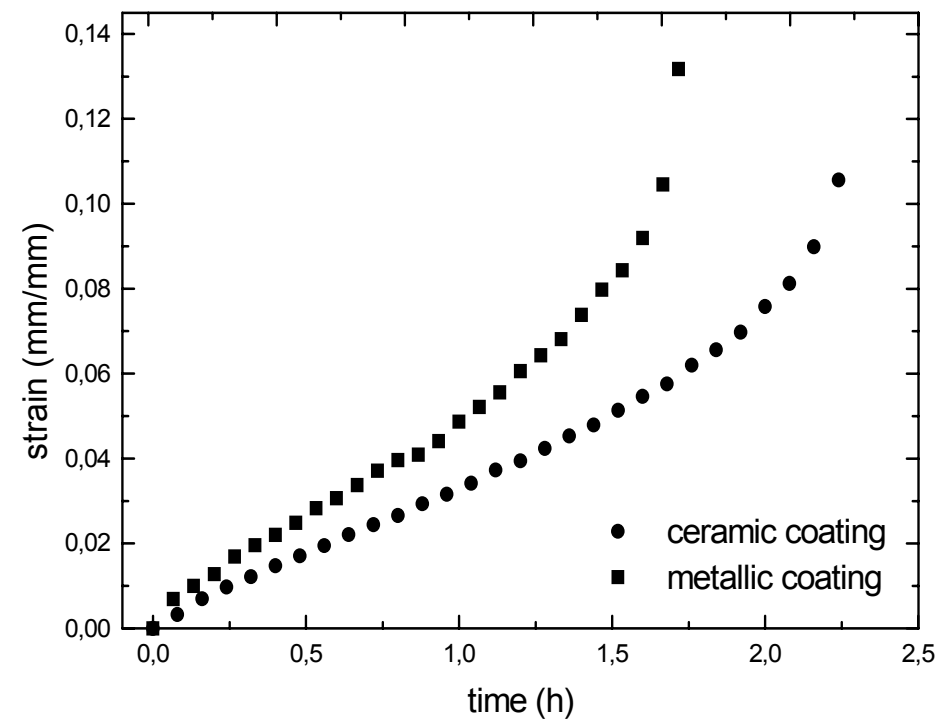

Fig. 1. Typical creep curves of Ti-6Al-4V at $500^{\circ} \mathrm{C} / 520 \mathrm{MPa}$. 
The Fig.2 shows a Ti-6Al-4V alloy micrographic as received. The microstructure consists of equiaxed $\alpha(\mathrm{HC})$ grains with average size about $10 \mu \mathrm{m}$. The $\beta$ (CCC) phase is present in the $\alpha$ grain boundaries.

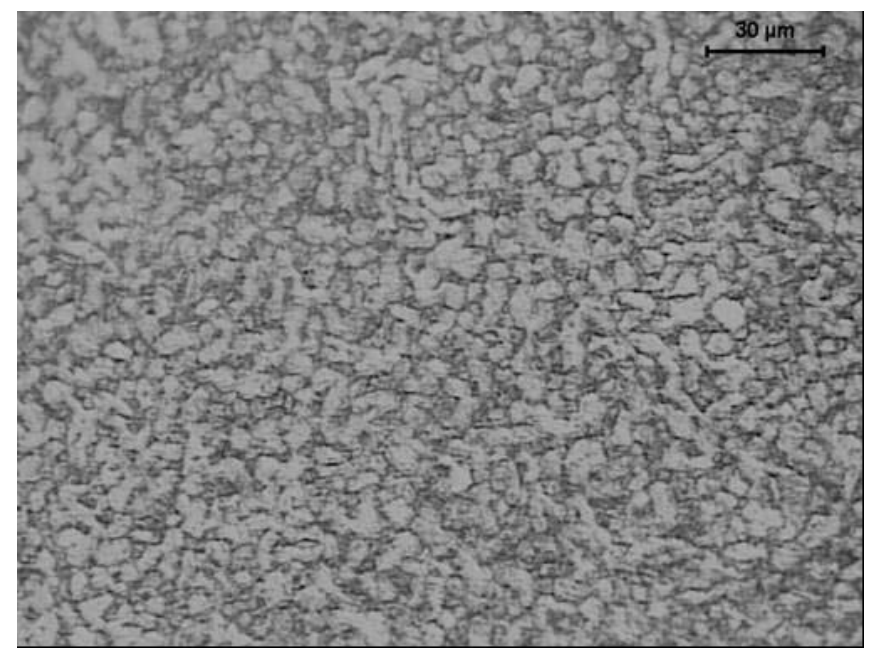

Fig. 2 - Micrograph of Ti-6Al-4V alloy as-received.

The Fig. 3 represents the longitudinal section of the sample tested under creep test at $500^{\circ} \mathrm{C}$, in air with metallic covered. Kroll reagent was used to attack the sample.
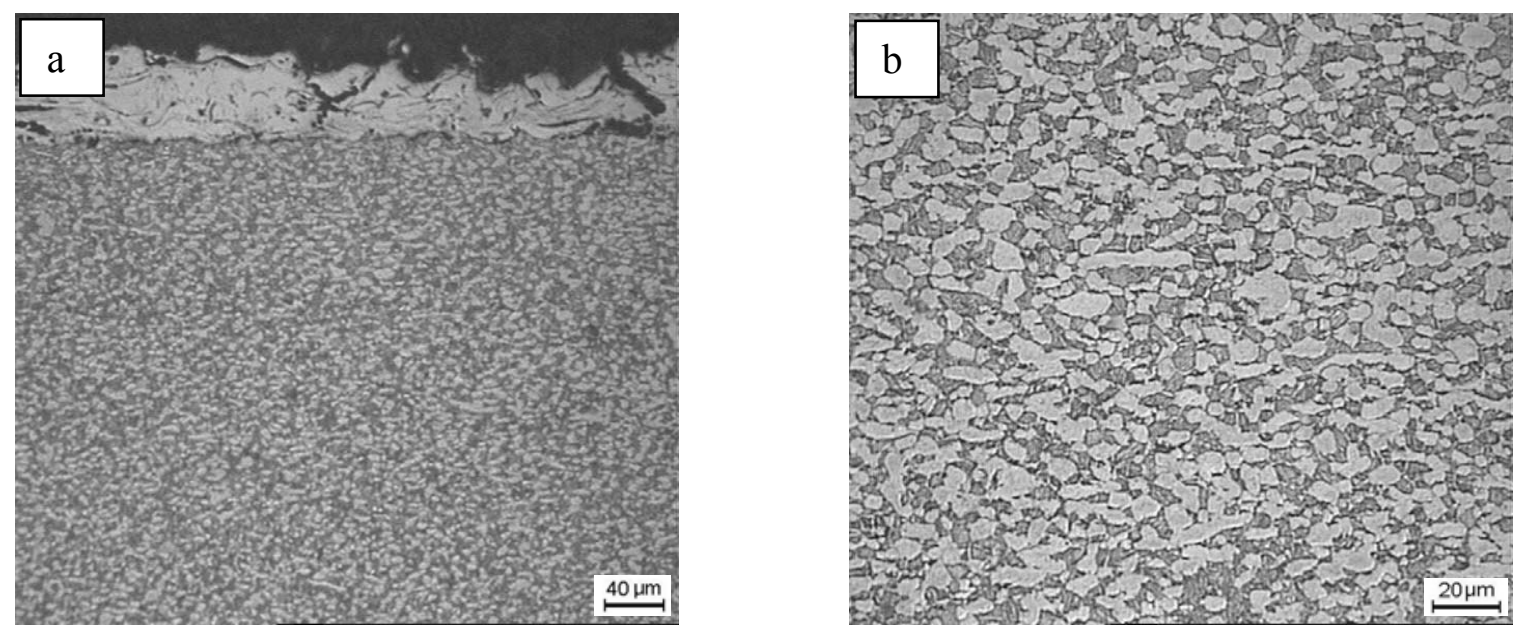

Fig. 3 - Longitudinal section of the sample tested under creep test at $500^{\circ} \mathrm{C}$, in air with metallic coating.

The micrographs show the grain growth of the alpha phase and beta dissolution; based on the initial microstructure before test it was continuous along grain boundaries. It can be considered a mechanism of microstrutural degradation together with the grain growth, formation of oxidation layers and superficial cracks, besides rupture in the coating layer.

The Fig. 4 shows the micrographs obtained by MEV of the coating applied on the Ti-6Al$4 \mathrm{~V}$ substrate. The thickness of the coating was $0.122 \mathrm{~mm}$ to the metallic coating and $0.806 \mathrm{~mm}$ to the ceramic coating. Using the semi-quantitative analysis by EDS it can get the composition values from each coating analyzed (Table 3 ). 

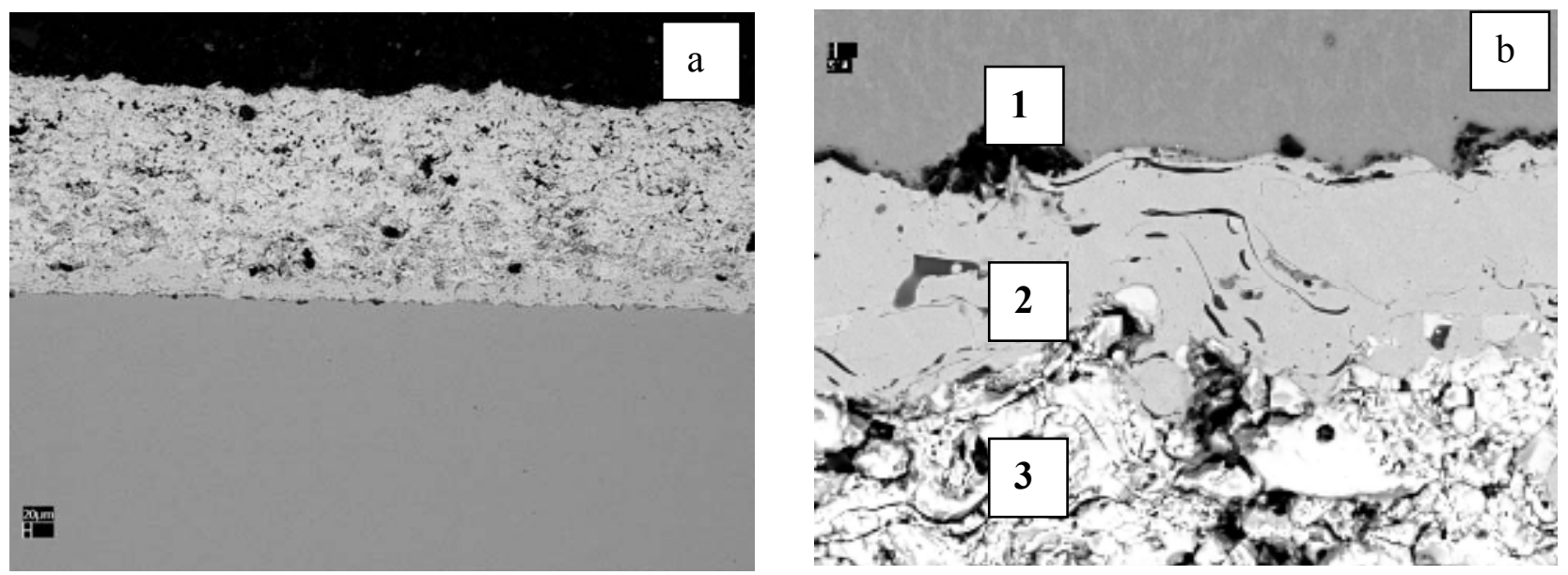

Fig. 4 - Micrographs obtained by MEV of the coating used in the Ti-6Al-4V substrate. a) Deposited coatings on titanium substrate, b) Amplified vision of deposited coatings on titanium substrate: 1) ceramic coating, 2) metallic coating and 3) Ti-6Al-4V substrate.

Table 3 - Semi-quantitative analysis of EDS of the analyzed surfaces.

\begin{tabular}{|c|c|c|c|}
\hline \multirow{2}{*}{ Elements } & \multicolumn{3}{|c|}{ Analyzed Surfaces } \\
\cline { 2 - 4 } & $\begin{array}{c}\text { Ceramic Coating } \\
(\mathrm{wt} \%)\end{array}$ & $\begin{array}{c}\text { Metallic Coating } \\
(\mathrm{wt} \%)\end{array}$ & $\begin{array}{c}\text { Substrate } \\
(\mathrm{wt} \%)\end{array}$ \\
\hline $\mathrm{O}$ & 16.06 & 1.40 & 2.08 \\
\hline $\mathrm{Al}$ & 0.17 & 6.61 & 5.04 \\
\hline $\mathrm{Ti}$ & 6.89 & 6.30 & 83.67 \\
\hline $\mathrm{V}$ & 0.32 & 0.24 & 4.74 \\
\hline $\mathrm{Cr}$ & 0.71 & 19.34 & 0.49 \\
\hline $\mathrm{Co}$ & 1.37 & 32.86 & 1.08 \\
\hline $\mathrm{Ni}$ & 1.27 & 29.07 & 0.91 \\
\hline $\mathrm{Y}$ & 5.34 & 0.65 & 0.06 \\
\hline $\mathrm{Zr}$ & 67.87 & 3.55 & 1.94 \\
\hline
\end{tabular}

\section{Conclusions}

The creep properties of Ti-6Al-4V alloy in air in ceramic and metallic coating samples at $500^{\circ} \mathrm{C}$. The ceramic coating increases the creep resistance of the alloy at $500^{\circ} \mathrm{C}$. The highest values of $t_{p}$ and the reduction of the steady-state creep rate demonstrate that the higher creep resistance of Ti-6Al-4V is observed in ceramic samples. This fact is related to the oxidation protection on creep that the ceramic plasma-sprayed coatings offer to the Ti-6Al-4V alloy.

\section{Acknowledgment}

FAPESP (Proc.02/04736-7) for financial support and Rolls-Royce Brasil (São Bernardo do Campo) for plasma-sprayed coatings.

\section{References}

[1] McKee, D.W. and Luthra, K.L. M., 1993, Surface and Coatings Technology, Vol. 56, pp. 109117. 
[2] Boyer, R. R., 1996, Mater. Sci. Eng. A, Vol. 213, pp.103.

[3] Abkowitz, S.;Burke, J. J. and Hiltz Jr., R. H., 1955, Technology of Structural Titanium. D. Van Nostrand Company, pp. 31-32.

[4] Seco, F. J. and Irisarri, A. M., 2001, Fatigue Fract. Eng. Mater. Struc., Vol. 24, pp.741.

[5] Gurrappa, I. and Gogia, A. K., 2001, Surface and Coatings Technology, Vol. 139, pp. 216-221.

[6] LaPierre, K.; Herman, H. and Tobin, A. G., 1991, Ceram. Eng. Sci. Proc., Vol. 12 (7-8), pp. 1201-1221.

[7] Xu, H.; Gong, S. and Deng, L., 1998, Thin Solid Films, Vol. 334, pp. 98-102.

[8] Sohn, Y. H.; Lee, E. Y.; Nagaraj, B. A.; Biederman, R. R. and Sisson Jr., R. D., 2001, Surface and Coatings Technology, Vol. 146-147, pp.132-139.

[9] Kucuk, A.; Berndt, C. C.; Senturk, U. and Lima, R. S., 2000, Mater. Sci. Eng. A, Vol. 284, pp. 41-50.

[10] Howard, E. B. and Timothy, L. G., 1985, Metals Handbook, Desk edition, ASM International.

[11] Annual Book of ASTM Standards, 1995, American Society of Testing and Materials. Philadelphia, PA, Vol.03.01, pp.129-136.

[12] Annual Book of ASTM Standards, 1995, American Society of Testing and Materials. Philadelphia, PA, Vol.03.01, pp. 257-267.

[13] Dyson, B. F. and Mc Lean, 1990, M. ISIJ Int., Vol.30, pp. 802.

[14] Barboza, M. J. R., 2001, Doctoral Thesis ITA, São José dos Campos, Brazil, 194p. 